\title{
EFEKTIVITAS BAHAN AKTIF HERBISIDA DAN VARIETAS TERHADAP PENGENDALIAN GULMA, PERTUMBUHAN DAN HASIL TANAMAN BAWANG MERAH (Allium ascalonicum L.)
}

\section{THE EFFECTIVENESS OF THE ACTIVE INGREDIENTS OF HERBICIDES AND VARIETIES ON WEED CONTROL,GROWTH AND YIELD OF SHALLOT PLANTS (Allium ascalonicum L.)}

\author{
Deden*, Dukat dan Subandi Nur \\ Fakultas Pertanian Universitas Swadaya Gunung Jati, Jawa Barat, Indonesia \\ Email: deden.ugj@gmail.com \\ * Corresponding Author, Diterima: 8 Jun. 2021, Direvisi: 1 Des. 2021, Disetujui: 20 Des. 2021
}

\begin{abstract}
Shallot now becomes a commodity that is reckoned in Indonesia because their existence is one of the determinants of inflation in the national economy. The presence of weeds among shallot plants is an obstacle and causes a decrease in the productivity of shallot yields, so it needs to be controlled appropriately, effectively, and efficiently. In addition, seeds are one of the main factors that determine the success of shallot farming. Efforts and strategies must continue to grown to increase shallot production, particularly efforts to control weeds and use appropriate seed varieties to increase the productivity of shallot plants. The study aimed to determine the effect of the active ingredients of herbicides and cultivars on weed control, growth, and yield of shallots. To find out the types of herbicide active ingredients and varieties that are most appropriate for weed control, growth, and yield of shallots. The trial be carried out in Desa Gagasari Kecamatan Gebang Kabupaten Cirebon from February to May 2021. The trial using a factorial Randomized Block Design (RBD) with three replications. The treatmens consisted of two factors, namely the first factor was the ingredients of herbicide ( $\mathrm{H}_{0}$ : Control, $\mathrm{H}_{1}:$ Farmer weeding, $\mathrm{H}_{2}:$ Oxyfluorfen, $\mathrm{H}_{-}:$: Pendimethalin), while the second factor is 2 varieties of shallot $\left(V_{1}:\right.$ Bima Variety, $V-_{-}:$: Ilocos Variety and $V_{-}$: Varieties of Sumenep). The main observations were made on the phytotoxicity and biomass of weeds, plant height, number of leaves, and dry weight of shallot yields. The results showed that the Oxifluorfen and Pendimetalin herbicides do not poison shallots. Weed control treatment with Oxifluorfen and Pendimetalin herbicides on shallots was more effective than manual weeding. Independently, Oxifluorfen herbicide treatment was able to control weeds on shallot plants resulting in a dry bulb weight of shallot reaching $5.98 \mathrm{~kg} / 9 \mathrm{~m} 2$ or equivalent to 12.57 tons/hectare. The ilokos variety independently produced a higher dry tuber weight than the Bima and Ilokos varieties, reaching $5.85 \mathrm{~kg} / 9 \mathrm{~m} 2$ or the equivalent of 12.16 tons/hectare.
\end{abstract}

Keywords: Herbicides, Shallots and Varieties

\section{ABSTRAK}

Bawang merah saat ini sudah menjadi komoditas yang diperhitungkan di Indonesia, karena keberadaanya menjadi salah satu variabel penentu inflasi secara ekonomi nasional. Kehadiran gulma diantara tanaman bawang merah menjadi kendala dan menyebabkan penurunan produktivitas hasil bawang merah, sehingga perlu dikendalikan secara tepat, efektif dan efisien. Selain itu, bibit merupakan salah satu faktor utama yang menentukan keberhasilan usaha tani bawang merah. Upaya dan strategi harus terus dikembangkan untuk dapat meningkatkan produksi bawang merah, khususnya upaya pengendalian gulma dan penggunaan varietas bibit yang tepat sehingga mampu meningkatkan produktivitas tanaman bawang merah. Tujuan penelitian adalah untuk mengetahui pengaruh bahan aktif herbisida dan varietas terhadap pengendalian gulma, pertumbuhan dan hasil bawang merah. Untuk mengetahui jenis bahan akif herbisida dan vaietas yang paling tepat untuk pengendalian gulma, pertumbuhan dan hasil bawang merah. Percobaan dilaksanakan di Desa Gagasari Kecamatan Gebang Kabupaten Cirebon.pada bulan Februari sampai dengan Mei 2021. Percobaan menggunakan Rancangan Acak Kelompok (RAK) pola faktorial dengan 3 kali ulangan. Perlakuan terdiri dari dua faktor yakni faktor pertama adalah bahan aktif herbisida $\left(\mathrm{H}_{0}\right.$ : Kontrol, $\mathrm{H}_{1}$ : Penyiangan petani, $\mathrm{H}_{2}$ : 
Oksifluorfen, $\mathrm{H}_{3}$ : Pendimetalin), sedangkan faktor kedua adalah 3 varietas bawang merah $\left(\mathrm{V}_{1}\right.$ : Varietas Bima, $\mathrm{V}_{2}$ : Varietas Ilokos dan $\mathrm{V}_{3}$ : Varietas Sumenep). Pengamatan utama dilakukan terhadap fitotoksitas dan biomasa gulma, tinggi tanaman, jumlah daun dan bobot kering hasil bawang merah. Hasil penelitian menunjukan bahwa herbisida Oksifluorfen dan Pendimetalin tidak meracuni bawang merah. Perlakuan pengendalian gulma dengan herbisida Oksifluorfen dan Pendimetalin pada tanaman bawang merah lebih efektif bila dibandingkan dengan penyiangan manual. Secara mandiri perlakuan herbisida Oksifluorfen mampu mengendalikan gulma pada tanaman bawang merah sehingga menghasilkan bobot umbi kering bawang merah mencapai 5,98 kg per $9 \mathrm{~m}^{2}$ atau setara dengan 12,57 ton/hektar. Secara mandiri varietas ilokos menghasilkan bobot umbi kering yang lebih tinggi bila dibandingkan dengan varietas Bima dan Ilokos, yaitu mencapai $5,85 \mathrm{~kg}$ per $9 \mathrm{~m}^{2}$ atau setara 12,16 ton/hektar.

Kata kunci: Gulma, Herbisida dan Varietas Bawang Merah

\section{PENDAhluLuan}

Bawang merah adalah salah satu komoditas penting bagi petani dan masyarakat secara umum. Potensi pengembangan dan peluang usaha bawang merah menjadi kian menjanjikan dan sangat terbuka lebar seiring meningkatnya permintaan akibat pertambahan penduduk dan perkembangan dunia insdustri di Indonesia. Ketersediaan bawang merah untuk memenuhi permintaan konsumen yang terus mengalami peningkatan perlu menjadi perhatian serius semua pihak. Umyati dkk, (2020), mengatakan bahwa kebutuhan terhadap bawang merah terus meningkat sejalan dengan pertambahan jumlah penduduk, peningkatan daya beli dan perkembangan industri makanan. Upaya dan strategi harus terus dikembangkan untuk dapat meningkatkan produksi bawang merah agar mampu meningkatkan daya beli masyarakat dan pendapatan petani. Upaya peningkatan produksi bawang merah nasional saat ini masih banyak terkendala yang disebabkan oleh banyak faktor, di antaranya cara budidaya yang kurang optimal, banyaknya OPT serta penggunaan satu jenis kultivar itu-itu saja yang ditanam terus-menerus (Kementerian Pertanian, 2017). Salah satu OPT yang mengganggu pertumbuhan bawang merah adalah kehadiran gulma. Kehadiran gulma di antara tanaman bawang merah menyebabkan kehilangan hasil saat panen, sehingga perlu dilakukan teknik budidaya agar tidak kehilangan hasil akibat gulma. Gulma yang berkompetisi dengan bawang merah mengakibatkan $87 \%$ pengurangan hasil umbi (Qasem, 2005). Sembodo (2010), menyatakan bahwa semakin lama jangka waktu (durasi) kehadiran gulma bersama tanaman akan semakin besar penurunan hasil akibat kompetisi yang terjadi. Gulma-gulma yang dominan pada tanaman bawang merah adalah gulma golongan daun lebar, teki, dan rumput (Umyati dkk, 2020).
Menurut Chattha et al (2004), aplikasi herbisida pratumbuh bersamaan dengan pengelolaan mekanis dapat membantu keuntungan di awal tanam. Penggunaan herbisida pratumbuh sangat penting untuk mencegah dari pembibitan dan seed bank benih gulma yang pada akhirnya akan berdampak pada komponen hasil (Fillols and Callow, 2010). Berbagai merek dagang dan bahan akif herbisida sangat banyak di lapangan, misalnya yang biasa digunakan petani bawang merah di antaranya bahan aktif Pendimetalin dan Oksifluorfen. Kondisi tersebut membuat petani memerlukan informasi untuk mengetahui bahan aktif apa yang seharusnya paling tepat digunakan. Crutcfiled dan Burnside (1994), menyatakan bahwa bahan aktif Oksifluorfen yang merupakan bahan aktif herbisida dari famili Diphenylether dengan mode of action menghambat enzim PPO (protoporphyrinogen oxidase). Menurut Maghfoer et al (1990), herbisida dengan bahan aktif Oksifluorfen pratumbuh dosis $360 \mathrm{~g} / \mathrm{ha}$ mampu menekan pertumbuhan gulma sampai 60 hari. Herbisida bahan aktif oksifluoren juga mengakibatkan kepadatan gulma lebih rendah (Ramalingam et al, 2013). Oksifluoren 1,5 1/ha memberikan panjang tanaman bawang merah yang sama dengan perlakuan kontrol (Permana dkk, 2018). Umiyati (2016), Oksifluorfen $240 \mathrm{~g} / \mathrm{l}$ dengan dosis 2 1/ha menunjukkan rata-rata berat umbi basah bawang merah yang tinggi yaitu $24.15 \mathrm{~kg} / 9 \mathrm{~m}^{2}$ Bahan aktif herbisida lainya adalah Pendimetalin, Pendimetalin termasuk dalam golongan herbisida dinitroanilin, dengan mode of action menghambat perkembangan akar dan tajuk gulma yang baru berkecambah (Sembodo 2010). Pendimetalin 1000 $\mathrm{g} / \mathrm{ha}$ mampu mengendalikan gulma dan secara signifikan memberikan perubahan pada panjang tanaman bawang merah umur 60 hari setelah tanam (HST) jika dibandingkan dengan Kontrol. Vashi et al. (2011), menyatakan bahwa Pendimethalin $1 \mathrm{~kg} /$ 
ha secara pratumbuh berpengaruh secara signifikan terhadap bobot umbu bawang merah. Herbisida Pendimetalin dan Oksifluoren efektif dalam mengendalikan gulma dan meningkatkan hasil pada bawang merah (Shinde et al. 2013). Pengendalian gulma dengan aplikasi herbisida oksifluorfen 1,51/ hektar dan pengendalian gulma dengan aplikasi pendimethalin $1.000 \mathrm{~g} /$ hektar yang diaplikasikan secara pratumbuh dapat menghasilkan panen sebesar 15,23 ton/hektar, 13,61 ton/hektar atau meningkat sekitar 52,70\%, 57,73\% dibandingkan dengan perlakuan penyiangan manual (Permana $\mathrm{dkk}, 2018$ ).

Upaya lainya untuk meningkatlkan produksi bawang merah adalah dengan penggunaan varietas yang tepat. Pemerintah telah melepas banyak varietas-varietas unggul bawang merah, akan tetapi di lapangan hanya beberapa varietas tertentu yang diminati atau sering digunakan petani. Hal ini diduga disebabkan karena tidak semua varietas yang telah dilepas tersebut sesuai dengan spesifik lokasi daerah-daerah sentra bawang merah, seperti Cirebon dan sekitarnya. Varietas bibit merupakan salah satu faktor utama yang menentukan keberhasilan usaha tani bawang merah. Saat ini varietas bibit bawang merah yang tersedia dikalangan petani adalah bibit-bibit yang diduga sudah berubah dari sifat-sifat benih asalnya. Kondisi ini menyebabkan kerentanan terhadap serangan hama dan penyakit dan tidak kompetitif terhadap gulma sehingga produktivitasnya menjadi menurun. Salah satu varietas bawang merah yang biasa digunakan di wilayah Cirebon dan sekitarnya dan dinilai baik produksinya di antaranya adalah varietas Bima, Ilokos dan Sumenep. Produksi umbi varitas Bima 9,9 ton/ha, Varietas Sumenep 11,94 ton/ha dan varietas Ilokos 13,33 - 19,44 ton/ha (Balitsa, 2018).

\section{BAHAN DAN METODE}

Percobaan dilaksanakan di Desa Gagasari Kecamatan Gebang Kabupaten Cirebon. Bahan yang digunakan adalah bahan aktif herbisida (Pendimetalin dan Oksifluorfen) dan 3 varietas bibit bawang merah (Bima, Ilokos dan Sumenep). Pupuk Urea (N) $600 \mathrm{~kg} / \mathrm{ha}$, pupuk SP-36 (P) $300 \mathrm{~kg} / \mathrm{ha}$, dan pupuk $\mathrm{KCl}(\mathrm{K}) 200 \mathrm{~kg} / \mathrm{ha}$, pengendalian OPT menggunakan pestisida. Alat-alat yang digunakan di antaranya alat pertanian dan alat perlengkapan laboratorium. Metode menggunakan Rancangan Acak Kelompok (RAK) pola faktorial. Perlakuan terdiri dari dua faktor yakni faktor pertama jenis bahan aktif herbisida $\left(\mathrm{H}_{0}\right.$ : Kontrol, $\mathrm{H}_{1}$ : Penyiangan petani, $\mathrm{H}_{2}$ : Herbisida b.a Oksifluorfen dan $\mathrm{H}_{3}$ : Herbisida b.a Pendimetalin) dan faktor kedua adalah varietas bawang merah $\left(\mathrm{V}_{1}\right.$ : Varieats Bima, $\mathrm{V}_{2}$ : Varietas Ilokos dan $\mathrm{V}_{3}$ : Varietas Sumenep). Masing-masing perlakuan diulang tiga kali sehingga jumlah petak dalam penelitian sebanyak $4 \times 3 \times 3=$ 36 petak. Ukuran petak 1,5 m x $6 \mathrm{~m}$, jarak antar petak (lebar solokan) $30 \mathrm{~cm}$, jarak antar ulangan $50 \mathrm{~cm}$, dan menggunakan jarak tanam $15 \mathrm{~cm}$ x 15 $\mathrm{cm}$. Pengamatan utama dilakukan pada variabel fitotoksitas, biomassa gulma, tinggi tanaman, jumlah daun dan hasil bobot kering bawang merah. Herbisida diaplikasikan 1 kali pada 7 hari sebelum tanam menggunakan alat semprot punggung semiotomatis. Dosis yang digunakan adalah 21 /hektar, volume air 500 1/ha, alat semprot dan nozel T-jet bertekanan 1 kg/cm2 (15-20 psi) (Umiyati, 2020).

\subsection{Analisis Data}

Pengolahan data dikerjakan dengan metode sidik ragam dan uji jarak berganda Duncan. Apabila perlakuan menunjukan pengaruh nyata maka dilakukan uji lanjut terhadap perbedaan nilai ratarata pada taraf kepercayaan $95 \%$ dengan prosedur uji yang sesuai dengan rancangan percobaan.

\section{HASIL DAN PEMBAHASAN}

\subsection{Fitotoksitas (\%)}

Data pada Tabel 1 menunjukkan bahwa perlakuan herbisida (Oksifluorfen dan Pendimetalin) tidak menimbulkan fitotoksitas atau keracunan bagi tanaman bawang merah, berdasarkan hasil tersebut, maka proses pertumbuhan dan perkembangan tanaman dapat berjalan dengan baik. Hasil tersebut ternyata sejalan dengan hasil penelitian Umiyati dkk (2016), bahwa penggunaan herbisida Oksifluorfen $240 \mathrm{~g} / 1$ dengan kisaran dosis 240-720 g/ha tidak menimbulkan gejala keracunan pada tanaman bawang merah. Penelitian lainya dari Umiyati (2020), menyataka bahwa herbisida campuran ((b.a.: Pendimetalin 150 $\mathrm{g} / 1+$ Metolaklor $300 \mathrm{~g} / 1+$ Oksifluorfen $50 \mathrm{~g} / \mathrm{l}$ ) dengan kisaran dosis $1,01 /$ ha $-3,501 /$ ha tidak menimbulkan gejala keracunan pada tanaman bawang merah. Oksifluorfen merupakan herbisida yang bersifat selektif yang dapat mengendalikan gulma tetapi tidak mempengaruhi pertumbuhan tanaman bawang bawang merah atau tidak menyebabkan fitotoksitas bagi tanaman sehingga 
Tabel 1. Pengaruh Fitotoksitas Bahan Aktif Herbisida dan Varietas Tanaman Bawang Merah (Allium ascalonicum L.) pada Umur Pengamatan 1, 2 dan 3 MSA (\%).

\begin{tabular}{lccc}
\hline \multicolumn{1}{c}{ Perlakuan } & \multicolumn{3}{c}{ Rata-rata Fitotoksitas (\%) } \\
\cline { 2 - 4 } \multicolumn{1}{c}{ Perlakuan Herbisida (H) } & 1 MSA & MSA & $3 \mathrm{MSA}$ \\
\hline $\mathrm{H}_{0}=$ Kontrol & $0,00 \mathrm{a}$ & $0,00 \mathrm{a}$ & $0,00 \mathrm{a}$ \\
$\mathrm{H}_{1}=$ Penyiangan Petani & $0,00 \mathrm{a}$ & $0,00 \mathrm{a}$ & $0,00 \mathrm{a}$ \\
$\mathrm{H}_{2}=$ Herbisida b.a. Oksifluorfen & $0,00 \mathrm{a}$ & $0,00 \mathrm{a}$ & $0,00 \mathrm{a}$ \\
$\mathrm{H}_{3}=$ Herbisida b.a Pendimatelin & $0,00 \mathrm{a}$ & $0,00 \mathrm{a}$ & $0,00 \mathrm{a}$ \\
$\quad$ Perlakuan Varietas Bawang Merah (V) & & & \\
$\mathrm{V}_{1}=$ Varietas Bima & $0,00 \mathrm{a}$ & $0,00 \mathrm{a}$ & $0,00 \mathrm{a}$ \\
$\mathrm{V}_{2}=$ Varietas Ilokos & $0,00 \mathrm{a}$ & $0,00 \mathrm{a}$ & $0,00 \mathrm{a}$ \\
$\mathrm{V}_{3}=$ Varietas Sumenep & $0,00 \mathrm{a}$ & $0,00 \mathrm{a}$ & $0,00 \mathrm{a}$ \\
\hline
\end{tabular}

Keterangan : Angka rata-rata yang diikuti huruf yang sama pada kolom dan faktor yang sama, tidak berbeda nyata menurut Uji Jarak Berganda Duncan pada taraf 5\%.

Table 2. Efektivitas Bahan Aktif Herbisida dan Varietas Bawang Merah terhadap Biomassa Gulma (gram).

\begin{tabular}{lc}
\hline \multicolumn{1}{c}{ Perlakuan } & Biomassa per $9 \mathrm{~m}^{2}$ \\
\cline { 2 - 2 }$\quad$ Perlakuan Herbisida $(\mathrm{H})$ & $($ gram $)$ \\
\hline $\mathrm{H}_{0}=$ Kontrol & $42,18 \mathrm{c}$ \\
$\mathrm{H}_{1}=$ Penyiangan Petani & $19,09 \mathrm{~b}$ \\
$\mathrm{H}_{2}=$ Herbisida b.a. Oksifluorfen & $6,82 \mathrm{a}$ \\
$\mathrm{H}_{3}=$ Herbisida b.a Pendimatelin & $9,31 \mathrm{a}$ \\
$\quad$ Perlakuan Varietas Bawang Merah (V) & $17,37 \mathrm{a}$ \\
$\mathrm{V}_{1}=$ Varietas Bima & $19,00 \mathrm{a}$ \\
$\mathrm{V}_{2}=$ Varietas Ilokos & $21,68 \mathrm{~b}$ \\
$\mathrm{~V}_{3}=$ Varietas Sumenep & \\
\hline
\end{tabular}

Keterangan : Angka rata-rata yang diikuti huruf yang sama pada kolom dan faktor yang sama, tidak berbeda nyata menurut Uji Jarak Berganda Duncan pada taraf 5\%.

pertumbuhan tetap tumbuh optimal (Zimdahl, 2007). Aplikasi herbisida pendimethalin tidak menyebabkan gejala fitotoksisistas pada tanaman bawang merah (Rolenzah, 2013).

\subsection{Biomassa Gulma}

Berdasarkan hasil pengamatan yang tersaji pada Tabel 2, terlihat tidak ada perbedaan yang nyata hasil biomassa gulma akibat perlakuan herbisida, baik Oksifluoren maupun Pendimetalin. Bila dibandingkan dengan perlakuan kontrol dan perlakuan penyiangan manual yang biasa dilakukan oleh petani, perlakuan herbisida menunjukan perbedaan yang nyata dalam mengendalikan biomassa gulma. Hal tersebut mengindikasikan bahwa pengendalian gulma dengan herbisida lebih efektif dilakukan bila dibandingkan dengan pengendalian yang biasa dilakukan oleh petani dengan cara dicabut berkala tanpa herbisida.
Herbisida berpengaruh terhadap persentase pengendalian gulma dan persentase penutupan gulma (Nosan, 2019). Penelitian Permana (2018) menunjukkan bahwa aplikasi herbisida oksifluorfen dan Pendimetalin berpengaruh terhadap rata-rata hasil bobot kering (biomassa) gulma.

Biomassa gulma pada varietas Sumenep lebih tinggi bila dibandingkan dengan biomassa gulma pada varietas Ilokos dan Bima, sedangkan biomassa pada varietas Ilokos dan Bima tidak menunjukan perbedaan yang nyata. Hal tersebut diduga karena varietas Bima dan Ilokos lebih memiliki daya adptasi yang kuat terhadap lingkungan tumbunya, utamanya kemampuan penyerapan hara sehingga mampu berkompetisi dalam perebutan unsur hara, akhirnya mampu menekan pertumbuhan gulma. Brewster (1994) menyatakan bahwa tanaman bawang merah yang bersifat lebih peka dibandingkan tanaman lainnya (gulma), mampu bersaing dalam pengambilan hara dalam tanah. 


\subsection{Tinggi Tanaman}

Pada Tabel 3, menunjukan bahwa perlakuan herbisida Oksifluorfen secara mandiri menunjukan hasil tinggi tanaman yang lebih tinggi bila dibandingkan dengan perlakuan kontrol, penyiangan petani dan herbisida Pendimatalin. Umiyati (2016), mengemukakan bahwa tanaman pada perlakuan herbisida Oksifluorfen dengan dosis 1 liter/ha pada pengamatan 4-3 msa menunjukkan tinggi tanaman yang lebih tinggi dibandingkan dengan perlakuan kontrol, penyiangan petani dan Pendimatalin. Sementara itu perlakuan herbisida bahan aktif lainya (Pendimetalin) yang diuji pada penelitian ini tidak menunjukan perbedaan hasil yang nyata terhadap tinggi tanaman, bahkan bila dibandingkan dengan perlakuan kontrol sekalipun. Hal tersebut sejalan dengan hasil penelitian Rolenzah (2013), yang mengemukakan bahwa herbisida Pendimethalin tidak berpengaruh terhadap pertumbuhan vegetatif tanaman bawang merah. Perlakuan varietas menunjukan perbedaan yang nyata terhadap hasil pengamatan tinggi tanaman. Pada perlakuan variatas secara mandiri Sumenep menunjukan hasil tinggi tanaman yang lebih tinggi dari varietas Bima dan Ilokos. Hal tersebut diduga karena sesuai deskripsinya bahwa varietas sumenep memiliki tinggi yang lebih bila dibandingkan dengan dua varietas lainnya yang diuji.

\subsection{Jumlah Daun}

Berdasarkan hasil pengamatan pada Tabel di atas, jumlah daun bawang merah dipengaruhi oleh perlakuan herbisida dan varietas. Perlakuan penyiangan petani dan herbisida berbeda nyata jika dibandingkan dengan kontrol. Perlakuan penyiangan petani dan herbisida berpengaruh terhadap hasil

Table 3. Pengaruh Efektivitas Bahan Aktif Herbisida dan Varietas terhadap Tinggi Tanaman Bawang Merah (Allium ascalonicum L.) pada Umur Pengamatan 21, 28 dan 35 HST (cm).

\begin{tabular}{lccc}
\hline \multirow{2}{*}{ Perlakuan } & \multicolumn{3}{c}{ Rata-rata Tinggi Tanaman $(\mathrm{cm})$} \\
\cline { 2 - 4 } \multicolumn{1}{c}{ Perlakuan Herbisida (H) } & 21 HST & $28 \mathrm{HST}$ & $35 \mathrm{HST}$ \\
\hline $\mathrm{H}_{0}=$ Kontrol & & & \\
$\mathrm{H}_{1}=$ Penyiangan Petani & $23,51 \mathrm{a}$ & $29,39 \mathrm{a}$ & $34,06 \mathrm{a}$ \\
$\mathrm{H}_{2}=$ Herbisida b.a. Oksifluorfen & $23,94 \mathrm{a}$ & $29,41 \mathrm{a}$ & $34,63 \mathrm{a}$ \\
$\mathrm{H}_{3}=$ Herbisida b.a Pendimatelin & $25,71 \mathrm{~b}$ & $32,37 \mathrm{~b}$ & $36,26 \mathrm{~b}$ \\
$\quad$ Perlakuan Varietas Bawang Merah (V) & $24,41 \mathrm{a}$ & $29,83 \mathrm{a}$ & $34,27 \mathrm{a}$ \\
$\mathrm{V}_{1}=$ Varietas Bima & & & \\
$\mathrm{V}_{2}=$ Varietas Ilokos & $23,58 \mathrm{a}$ & $29,15 \mathrm{a}$ & $33,90 \mathrm{a}$ \\
$\mathrm{V}_{3}=$ Varietas Sumenep & $24,19 \mathrm{a}$ & $29,81 \mathrm{a}$ & $34,31 \mathrm{a}$ \\
\hline
\end{tabular}

Keterangan : Angka rata-rata yang diikuti huruf yang sama pada kolom dan faktor yang sama, tidak berbeda nyata menurut Uji Jarak Berganda Duncan pada taraf $5 \%$.

Table 4. Pengaruh Efektivitas Bahan Aktif Herbisida dan Varietas terhadap Jumlah Daun Tanaman Bawang Merah (Allium ascalonicum L.) pada Umur Pengamatan 21, 28 dan 35 HST (helai).

\begin{tabular}{lccc}
\hline \multirow{2}{*}{ Perlakuan } & \multicolumn{3}{c}{ Rata-rata Jumlah Daun (helai) } \\
\cline { 2 - 4 } & 21 HST & $28 \mathrm{HST}$ & $35 \mathrm{HST}$ \\
\hline \multicolumn{1}{c}{ Perlakuan Herbisida $(\mathrm{H})$} & & & \\
$\mathrm{H}_{0}=$ Kontrol & $21,37 \mathrm{a}$ & $32,55 \mathrm{a}$ & $36,04 \mathrm{a}$ \\
$\mathrm{H}_{1}=$ Penyiangan Petani & $21,96 \mathrm{a}$ & $34,96 \mathrm{c}$ & $37,29 \mathrm{~b}$ \\
$\mathrm{H}_{2}=$ Herbisida b.a. Oksifluorfen & $22,66 \mathrm{a}$ & $39,18 \mathrm{~d}$ & $40,22 \mathrm{~d}$ \\
$\mathrm{H}_{3}=$ Herbisida b.a Pendimatelin & $23,64 \mathrm{a}$ & $34,41 \mathrm{~b}$ & $38,19 \mathrm{c}$ \\
$\quad$ Perlakuan Varietas Bawang Merah (V) & & & \\
$\mathrm{V}_{1}=$ Varietas Bima & $19,89 \mathrm{a}$ & $34,45 \mathrm{a}$ & $36,79 \mathrm{a}$ \\
$\mathrm{V}_{2}=$ Varietas Ilokos & $25,42 \mathrm{~b}$ & $36,61 \mathrm{~b}$ & $38,52 \mathrm{a}$ \\
$\mathrm{V}_{3}=$ Varietas Sumenep & $21,92 \mathrm{a}$ & $34,76 \mathrm{a}$ & $38,50 \mathrm{a}$ \\
\hline
\end{tabular}

Keterangan : Angka rata-rata yang diikuti huruf yang sama pada kolom dan faktor yang sama, tidak berbeda nyata menurut Uji Jarak Berganda Duncan pada taraf 5\%. 
Table 5. Pengaruh Efektivitas Bahan Aktif Herbisida dan Varietas terhadap Bobot Umbi Kering Bawang Merah (Allium ascalonicum L.) (kg).

\begin{tabular}{lc}
\hline \multicolumn{1}{c}{ Perlakuan } & Bobot Umbi Kering per $9 \mathrm{~m}^{2}$ \\
\cline { 2 - 2 }$\quad$ Perlakuan Herbisida $(\mathrm{H})$ & $(\mathrm{kg})$ \\
$\mathrm{H}_{0}=$ Kontrol & $5,65 \mathrm{a}$ \\
$\mathrm{H}_{1}=$ Penyiangan Petani & $5,74 \mathrm{a}$ \\
$\mathrm{H}_{2}=$ Herbisida b.a. Oksifluorfen & $5,98 \mathrm{c}$ \\
$\mathrm{H}_{3}=$ Herbisida b.a Pendimatelin & $5,82 \mathrm{~b}$ \\
$\quad$ Perlakuan Varietas Bawang Merah (V) & \\
$\mathrm{V}_{1}=$ Varietas Bima & $5,59 \mathrm{a}$ \\
$\mathrm{V}_{2}=$ Varietas Ilokos & $5,80 \mathrm{a}$ \\
$\mathrm{V}_{3}=$ Varietas Sumenep & $5,85 \mathrm{~b}$ \\
\hline
\end{tabular}

Keterangan : Angka rata-rata yang diikuti huruf yang sama pada kolom dan faktor yang sama, tidak berbeda nyata menurut Uji Jarak Berganda Duncan pada taraf 5\%.

rata-rata jumlah daun pada pengamatan 28 dan 35 HST, hasil terbaik diperoleh dari perlakuan herbisida dengan bahan aktif Oksifluorfen. Hal tersebut diduga karena penyiangan dan herbisida dapat mengurangi kompetisi taanaman dan gulma dalam memperebutkan unsur hara, terutama unsur hara $\mathrm{N}$ yang berperan dalam proses pertumbuhan. Menurut Rao (2000), kehadiran gulma di sekitar tanaman akan menjadi pesaing kebutuhan hidup dan menghambat akumulasi serta distribusi fotosintat dari sumber ke bagian limbung.

Khatimah (2011) menambahkan pertumbuhan tanaman tidak akan tercapai tanpa adanya suplai $\mathrm{N}$ yang cukup. Nasreen et al., (2007) peningkatan tinggi tanaman dan jumlah daun tanaman disebabkan karena hara $\mathrm{N}$ terlibat langsung dalam pembentukan asam amino, protein, asam nukleat, enzim, nukleoprotein dan alkaloid yang sangat dibutuhkan untuk proses pertumbuhan tanaman, terutama perkembangan daun, meningkatkan warna daun, serta pembentukan cabang atau anakan. Perlakuan jenis varietas menunjukan perbedaan yang nyata terhadap rata-rata jumlah daun. Varietas ilokos terlihat lebih banyak menghasilkan jaumlah daun bila dibandingkan dengan perlakuan jenis varietas lainya.

\subsection{Bobot Umbi Kering}

Hasil analisis statistik pada Tabel 7 menunjukan terdapat perbedaan hasil bobot umbi kering tinggi dari perlakuan herbisida, bila dibandingkan dengan perlakuan kontrol atau perlakuan penyiangan manual petani. Namun pada bila dibandingkan pada perlakuan herbisida, Oksifluorfen menghasilkan bobot kering lebih tinggi daripada perlakuan herbisida Pendimetalin. Hal tersebut diduga karena pengendalian dengan herbisida lebih efektif mengurangi populsasi gulma sehingga bawang merah dapat tumbuh dengan baik sehingga menghasilkan produktivitas yang lebih tinggi. Herbisida dapat menghasilkan bobot umbi bawang merah yang tinggi dikarenakan sampai umur 6 minggu setelah aplikasi gulma yang tumbuh di sekitar tanaman dapat dikendalikan (Umiyati, 2016). Permana dkk (2018), pengendalian gulma dengan aplikasi herbisida oksifluorfen dan pendimethalin dapat menghasilkan panen yang meningkat sekitar 52,70\% - 57,73\% dibandingkan dengan perlakuan penyiangan manual.

Pengendalian gulma dengan herbisida Oksifluorfen menunjukan perbedaan hasil yang nyata atau lebih baik bila dibandingkan dengan herbisida Pendimetalin. Penggunaan herbisida Oksifluorfen mampu menghasilkan bobot umbi kering 5,98 $\mathrm{kg}$ per $9 \mathrm{~m}^{2}$ atau setara dengan 12,57 ton/hektar. Herbisida oksifluorfen dapat meningkatkan persentase pengendalian gulma dan menurunkan persentase penutupan gulma (Nosan, 2019), sehingga mampu meningkatkan produktivitas tanaman. Perlakuan jenis varietas bawang merah menunjukan perbedaan hasil yang nyata terhadap bobot umbi kering per petak, varietas ilokos memberikan bobot hasil yang lebih tinggi bila dibandingkan varietas bima dan sumenep. Jenis varietas ilokos mampu menghasilkan bobot umbi kering 5,85 kg per $9 \mathrm{~m}^{2}$ atau setara 12,16 ton/hektar. Hal tersebut sesuai dengan deksripsi variteas ilokos yang mempunyai ukuran dan bobot yang lebih besar bila dibandingkan dengan 2 varietas lainya yang diuji. 


\section{KESIMPULAN}

Herbisida Oksifluorfen dan Pendimetalin tidak meracuni bawang merah. Perlakuan pengendalian gulma dengan herbisida Oksifluorfen dan Pendimetalin pada tanaman bawang merah lebih efektif bila dibandingkan dengan penyiangan manual. Secara mandiri perlakuan herbisida Oksifluorfen mampu mengendalikan gulma pada tanaman bawang merah sehingga menghasilkan bobot umbi kering bawang merah mencapai 5,98 $\mathrm{kg}$ per $9 \mathrm{~m}^{2}$ atau setara dengan 12,57 ton/hektar. Secara mandiri varietas ilokos menghasilkan bobot umbi kering yang lebih tinggi bila dibandingkan dengan varietas Bima dan Ilokos, yaitu mencapai $5,85 \mathrm{~kg}$ per $9 \mathrm{~m}^{2}$ atau setara 12,16 ton/hektar.

\section{UCAPAN TERIMA KASIH}

Hormat dan ucapan terima kasih disampaikan kepada Ketua YPSGJ dan jajaran, Rektor dan jajaran, Kepala Lembaga Penelitian dan jajaran, Dekan Pertanian dan seluruh Civitas akademika UGJ Cirebon serta pengelola Jurnal Agrotek Tropika Universitas Lampung dan semua pihak yang berkontribusi dalam pelaksanaan penelitian dan penulisan jurnal ini.

\section{DAFTAR PUSTAKA}

Balitsa. 2018. Bawang Merah Varietas Bima Brebes.https://balitsa.litbang.pertanian.go.id/ ind/index.php/varietas/cabai/36-halaman/ 616-bawang-merah-varietas-bima-brebes. diakses pada tanggal 20 Mei 2021

Baswarsiati, F. Kasijadi dan L. Rosmahani. 2000. Rakitan Teknologi Usaha tani Bawang Merah. Monograf rakitan Teknologi BPTP Karangploso.

Brewster, J.L. 1994. Onion and other vegetable Alliums. CAB International, Cambridge. 236p.

Chattha, A.A., M. Afzal and M.U Chattha. 2004. Susitanable cultivation of sugarcane for revival of sugar industry in Pakistan. Proc. 39tn Ann. Conv. Pak. Sos. Sugar Tech : 36-49

Fillols, E.F.J and B.G Callow. 2010. Efficiency of pre-emergent herbicide on fresh trash blankets - results on late-harvested on lateharvested ratoons. Proc. of. the Aust. Soc. ofSugarcane Technologist. 32 : 460-473.

Kementrian Pertanian. 2017. Bertanam Bawang Merah Tak Kenal Musim. Pusat Perpustakaan dan Penyebaran Teknologi Pertanian. Jakarta. IAARD press.

Khatimah, H. 2011. Pengaruh BeberapaJarak Tanam Terhadap Pertumbuhan dan Hasil Varietas Baby Mentimun 007 F1. Universitas Muhammadiyah Sumatera Barat. Payakumbuh. 15 hal.

Maghfoer, M.D., E. Widaryanto dan Febriana. 1990. Pengaruh Herbisida Oksifluorfen (Goal 2E) dan Waktu Penyiangan terhadap Pertumbuhan dan Hasil Bawang Merah (Allium ascalonicum L.) Var. Bali Hijau. Pros. Konferensi X HIGI. Malang. Hal. 385.

Nasreen, S., M. M. Haque, M. A. Hosain dan Farid. 2007. Nutrient Uptake And Yield Of Union As Influenced By Nitrogen And Sulphur Fertilization. J. Agril. Res. Bangladesh.

Nosan, T. 2019. Aplikasi Herbisida Oksifluorfen dan Pendimethalin Pada Berbagai Dosis Serta Pengaruhnya Terhadap Gulma dan Hasil Bawang Merah (Allium ascalonicum L.). Etd Unsyiah

Permana J., W. Eko, dan P. J. Kurniawan. 2018. Penggunaan herbisida oksifluorfen dan pendimethalin pada tanaman bawang merah (Allium ascalonicum L.). J. Produksi Tanaman. 6 (4) :561-568

Qasem, J. R. 2005. Chemical control of weeds in onion (Allium cepa L.). J. Hortic. Sci. Biotechnol. 80 (6) : 721-726

Ramalingam, S.P., Ch. Chinnagounder, M. Perumal and M.A. Palanisamy. 2013. Evaliation of new formulatinon of oxyfluorfen $(23 \%$ EC) for weed control efficacy and bulb yield in onin. Amer. J. Plant Sci. 4(4) : 890-895.

Rao, V.S. 2000. Principles of Weed Science. Science Publishers Inc., California, USA.

Rolenzah, IP. 2013. Keefektivan Herbisida Pendimethalin untuk Pengendalian Gulma Pada Budidaya Tanaman Bawang Merah. Departemen Agronomi dan Hortikultura Fakultas Pertanian. Institut Pertanian Bogor.

Sembodo, D. R. J. 2010. Gulma dan Pengelolaanya. Graha Ilmu. Yogyakarta.

Shinde, K.G., M.N. Bhalekar and B.T. Patil. 2013. Effect of herbicides on weed intensity, weed control efficiency and yield in Kharifonion cv. Phule Samarth. Veg. Sci.40 (1) : 93-99

Umiyati, U. 2016. Studi efektivitas herbisida oksifluorfen 240 gl-1 sebagai pengendali 
gulma pada budidaya bawang merah (Allium ascalonicum L.). Jurnal Kultivasi Vol. 15(1)

Umiyati U, D. Kurniadie dan Deden. 2020. Efektivitas Herbisida Campuran b.a.: Pendimetalin $150 \mathrm{~g} / 1+$ Metolaklor $300 \mathrm{~g} / \mathrm{l}+$ Oksifluorfen $50 \mathrm{~g} / 1$ Untuk Mengendalikan Gulma Pada Budidaya Bawang Merah. Jurnal AGROSWAGATI 8 (1)
Vashi, J. M., N.K. Patel and D.T Desai. 2011. Evaluation of different herbicides for controlling weeds in onion (Allium cepa $\mathrm{L}$ ) Veg. Sci. 38 (1) : 119-120

Zimdahl, R.L. 2007. Fundamentals of Weed Science. 3th Academic press. Now York. 